\title{
James C. Sesil, Maya K. Kroumova, Douglas L. Kruse, Joseph R. Blasi*
}

\section{Broad-based Employee Stock Options in the U.S. - Company Performance and Characteristics ${ }^{* *}$}

This paper analyses data on 490 companies with broad-based stock option plans, matched to data from CompuStat in order to compare their characteristics and performance to that of other public companies. Major findings are that 1) companies with broadbased plans have higher levels of labor productivity, employment growth, and sales growth than otherwise-similar firms; 2) productivity and profitability levels rise as broadbased plans are adopted, and 3) average compensation levels are higher among such companies both before and after the introduction of broad-based plans, indicating that stock options appear to come on top of other compensation.

Key words: Broad-based Stock Options, Firm Performance, Wage Effect

* James C. Sesil, Douglas L. Kruse, Joseph R. Blasi, all Rutgers University, School of Management and Labor Relations, 94 Rockafeller Road, Piscataway, New Jersey 08854-8054, USA.

James C. Sesil : Phone: ++001 732 445-5997, Fax: ++1 732 445-5188,

e-mail: sesil@rci.rutgers.edu

Douglas L. Kruse, e-mail: dkruse@rci.rutgers.edu

Maya K. Kroumova, New York Institute of Technology, School of Management, 1855 Broadway, New York, NY 10023, USA. Phone : ++1 212261 1667, Fax: ++1 212261 1593, e-mail: mkroumov@nvit.edu

** The authors would like to thank Steve Director for his helpful comments and the National Center for Employee Ownership (NCEO) and their partners for providing access to the survey data. We would like to thank participants at the IRRA study group on pay systems and the Academy of Management session on stock options. We would also like to thank Ethan Tsai, Rhokeun Park and Ching-Bin Lin for their research assistance.

Article received: January 4, 2006

Revised version accepted after double blind review: January 8, 2007. 
There is a growing body of research that finds the Anglo-American model of variable compensation to be emerging as the dominant model for variable compensation worldwide (Ferrarini/Moloney/Vespro, 2003). The use of stock options and other forms of equity compensation for executives and a broader set of employees has become increasingly common across Europe (Mercer, 2006). Due to poor stock options plan design, the accounting controversy, and in the case of the recent grant date backdating scandal, stock options in the U.S. have never fulfilled their promise. If Europe is to learn from the mistakes of the U.S., it is necessary to understand when and where stock options generally and broadly distributed stock options specifically, constitute an efficient incentive contract.

There is an increasing body of research which shows that stock options are associated with greater firm performance when broadly distributed to employees (Core/Guay 2001; Gerhart/Milkovich 1990; Ittner/Lambert/Larcker 2003; Kroumova/Sesil/Kruse/Blasi 2002; Sesil/Kroumova/Blasi/Kruse 2002). Much of this research, however, focuses on the use of broad-based stock options in high-technology industries, where they may play a special role encouraging knowledge-sharing and promoting innovation (Ittner et al., 2003; Sesil et al. 2002). The extent to which broadbased stock options have effects among other types of firms remains unknown.

In addition, there is no research on the impact that broad-based stock options have on employee-level outcomes such as compensation levels or employee turnover. Over the last twenty years, a shift has taken place towards compensating employees with variable and equity compensation (Sesil/Kruse/Blasi 2003). In light of the collapse or precipitous decline in the share prices of companies like Enron and WorldCom many employees at these companies found themselves in possession of worthless or near worthless stock. A crucial question that needs to be addressed in research is if broad-based stock options are a complement or a substitute to fixed wages.

The purpose of this paper is to shed light on these two research questions: What impact do broad-based stock options have in firms in general (not just high technology firms), and, What is the relationship between broad-based stock option plans and employee wages? For the purposes of this paper, broad-based stock option companies are defined as those that make more than 50\% of their non-management employees eligible for stock option grants. A detailed empirical analysis is conducted, comparing the economic and financial performance of companies that grant broad-based stock options to the performance of companies that do not use stock options in their compensation package. We use profitability (ROA), productivity, Tobin's Q and wages as our dependent variables and also evaluate trends in shareholder returns.

We provide evidence here that broadly distributed stock options are associated with superior levels of firm productivity and profitability, and Tobin's q but we do not find any evidence of growth of these dependent variables. We also find broad-based stock options are a complement rather than a substitute for fixed wages.

\section{Theoretical background}

There is no accepted theoretical treatment associated with the performance potential of the use of stock options; however, we can draw from a number of theories to speculate on potential impact. Within agency theory, incentive conflicts arise because 
the interests of senior managers are not aligned with the interests of shareholders. In order to bring the interests of the two parties into closer alignment, owners incur cost in the form of monitoring and/or incentive contracts (Jensen/Meckling 1976). According to Eisenhardt (1988), agency theory presents a theoretical framework for thinking about which compensation plan to use in different organizational settings. Factors which need to be taken into consideration when determining the most efficient payment contract include: the possibility of self-interested misbehavior or moral hazard, the difficulty and cost of monitoring, the effects on effort associated with paying on the basis of performance, and the risk tolerance of the agent (Eisenhardt 1988). One mechanism used to bring the interests of these two parties into closer alignment is the allocation of stock to agents. Thus, the use of broad-based stock options is meant to provide incentives for employees at all levels in the organization to engage in the kinds of behaviors that will help their company be successful, and hence increase its market value.

The principal argument against any positive incentive effects of broad-based stock options is the weak line of sight between individual employee performance and any rewards from higher stock prices. (Sesil/Kroumova, 2006). The weak line of sight stems both from the fact that stock prices are affected by many things outside of workers' control, and from the free rider or $1 / \mathrm{N}$ problem of group incentive plans: with $\mathrm{N}$ workers sharing in rewards, each worker will get on average only $1 / \mathrm{N}$ of any extra rewards generated by his or her better performance (Sesil et al. 2003). As $N$ grows larger, workers have more incentive to be free riders off of the effort of others. The $1 / \mathrm{N}$ problem can also be seen as a form of the Prisoner's Dilemma from game theory, which may be overcome by a cooperative agreement among participants (Axelrod 1984; Ben-Ner/Jones 1995). Cooperative agreements in prisoner's dilemma games have been found to work through strong norms of reciprocity (Fehr/Gachter 2000). In addition, the experimental results of Carpenter (2004) show that performance may be as good in large groups as in small groups, since the tendency toward free riding in large groups may be counteracted by the increased number of people who are monitoring each free rider. Research on profit-sharing also indicates that group incentive plans can have positive effects in large firms (Kruse 1993).

What it takes to establish and maintain a productivity-enhancing cooperative agreement, however, has not been well-specified. There has been little work on the psychological and organizational mechanisms through which broad-based stock options are expected to bring about company success, but some insights can be gleaned from the broader literature on group incentive plans. Companies may be able to mitigate the impact of the $1 / \mathrm{N}$ problem through tools such as comprehensive performance management systems or other human resource policies and practices that help establish a corporate culture supporting a cooperative agreement. It has been argued that profit sharing plans can increase productivity by inducing cooperation and peer pressure, both of which can be cheap and effective substitutes for formal monitoring (Weitzman/Kruse 1990; Kruse 1993).

Stock options have the potential for focusing employee attention on the targets that are of interest to shareholders - share price and firm profitability (subject again to the line of sight problem). Increased information seeking by employees, especially if accompanied by increased information sharing, is another mechanism through which 
broad-based stock options might increase company performance. Employees have access to information that may be valuable to management. The presence of a group incentive plan may result in employees having the necessary incentive to communicate, or act on their superior information, because their interests are now more aligned with the interests of shareholders. The majority of the research associated with information sharing has evaluated top-down information sharing (Kleiner/Bouillon 1988; Morishima 1988). While Kleiner and Bouillon did not find a positive effect of information-sharing on performance measures, Morishima found that there was a positive association of information-sharing with profitability and productivity.

Stock options have also been credited as an effective tool for attracting better talent and reducing turnover (Ittner et al. 2003). Because options typically have a vesting requirement of several years, there is an incentive to stay on with the company, provided of course employees believe the company's stock will appreciate between the grant and exercise dates. The retention of difficult to imitate human capital may provide firms with a sustained competitive advantage ultimately positively impact firm performance. Given these numerous and conflicting dynamics it is difficult to state a declarative prediction regarding the predicted impact of broad-based stock options. The impact of options on company performance is an empirical question which we evaluate in this paper. However, on balance, given the line of sight and free-rider problems current theoretical treatments would not predict broad-based stock options to be associated with better firm performance.

\section{Broad-based stock options and other compensation}

Standard compensating differentials theory would predict that stock options generally replace another form of compensation, through lower wages (Milkovich/Newman 2002). Many start-up companies clearly do use stock options as substitutes for fixed wages (Weeden/Rosen/Carberry/Rodrick 2001). Existing evidence, however, tends to indicate that companies with profit-sharing or employee ownership tend to pay above market averages (Kruse 1993; Sesil et al. 2003), possibly because such group incentives complement high efficiency wages in increasing worker performance. It is possible that incentives such as stock options have a more positive effect on effort and performance when they are seen as add-ons to regular pay.

From a broader perspective, the full meaning of broad-based stock options for companies and employees cannot be properly estimated in a vacuum without understanding the trends in fixed compensation. Between 1982 and 1994, Hall/Liebman (1998) demonstrate that the total mean real growth of CEO compensation (salary + bonus + the value of stock option grants) was $175 \%$ or about $8.8 \%$ per year over the period. The median growth rates were $120 \%$ and $6.8 \%$, respectively. The comparable mean real growth rate for all wage and salary workers based on the Employment Cost Index was almost flat over the entire $1982-1994$ period at $7.2 \%$ or about $0.6 \%$ per year from $\$ 30,400$ in 1982 to $\$ 32,600$ in 1994 . They calculate that most of the real increase in CEO compensation was due to stock options and stock ownership (Hall/Liebman 1998: 665, Table III). For the period of 1994-1997, median weakly earnings growth on average equaled inflation, resulting in zero real wage growth (Bernstein/Mishel 2004). These trends suggest that, in the rising stock market of the mid 1990s, income from 
stock options and other forms of stock compensation may have helped provide rank and file employees with the potential for real wage growth.

The average value of stock option grants to rank-and-file employees appears to be non-trivial. According to Ittner et al. (2003), the average equity grant value for nonexempt employees in new economy firms in 1998-1999 was \$5,692 (median \$1,922), or $12.4 \%$ (median $10.8 \%$ ) of total compensation. For professional and sales employees, average grants ranged from $\$ 60,000$ to $\$ 100,000$. Using the same dataset we conducted our analysis using a sample that represents both new and old economy firms, the NCEO estimated that the average grant value in 1999 at $\$ 7,982$ for hourly employees and $\$ 35,481$ for technical employees (Weeden et al. 2001).

A number of economic researchers have noted that ownership of company stock puts employees at greater risk and that it would be possible for the employee to have a more diversified portfolio and less risk. Benartzi/Thaler (2001) found that employees over-invest in equities when company stock is offered as a choice in defined contribution plans and end up with $70 \%$ vs 50\% in equities. Benartzi (2001) notes that a substantial proportion of large retirement plan $401 \mathrm{k}$ investments are in company stock and that employees also put a significant percentage of their discretionary investments into the company stock account in these plans. He provides evidence that when the company stock performs well in the past, an increase in the allocation of individuals' investments in company stock takes place. Thus, he says this is an excessive extrapolation of past returns to predict uncertain future returns. Because stock options differ from employee share purchase programs (e.g. employees typically do not make cash payment for options), the extrapolation of past performance to future results may not be a big issue, however, it may well impact if they are willing to accept a reduction in base salary.

A pertinent literature to our work here is the work in the financial economic literature examining the value employees assign to stock options. There is a substantial body of work in this literature that provides evidence that employees value stock options less than formal valuation models because these models generally assume the employee to be risk neutral or averse (Hall/Murphy 2002; Hall/Murphy 2003; Johnson/Tian 2000). Lambert/Larcker/Verracchia, 1991 evaluates whether the risk level associated with options will vary dependent on whether or not they are viewed as a substitute or a complement to fixed wages. They find that if viewed as a substitute for fixed wages employees tend to value options less. However, much of this work is based on assumptions about employee wealth, risk tolerance and utility function (Hall/Murphy 2002). In recent work by Hallock and Olson (2006) directly evaluate employee exercise behaviors rather than evaluating outcomes associated with assumptions. They find that the formal valuation models such as Black-Scholes underestimate the value employees assign to stock options. These findings have direct bearing on our research; if risk averse employees are given stock options as a substitute for other forms of compensation, this may dilute a potential incentive or retention effect.

In summary, we see from our theoretical overview that there are a number of conflicting dynamics present and ultimately whether stock options are a complement or a substitute for fixed wages is an empirical question which we test. In addition, if indeed we find that stock options are a substitute for fixed wages we may also expect 
to see poorer performance (e.g. potentially greater turnover, reduced incentive effects for risk-averse employees). Again, however, the inverse may be true if stock options are a complement to fixed wages (potentially greater incentive effect and a reduction in employee turnover).

\section{Methods}

\section{Sample and procedures}

The National Center for Employee Ownership (NCEO), using newspaper, magazine, and press release reports in the national media, as well as information from consultants, compiled a list of public and private companies sponsoring some form of broadbased stock option plan in 1998, of which 490 were public companies that could be matched to Compustat. A 1998 NCEO survey of all companies on their list yielded 105 responses from these 490 companies. Among the 105 companies, 73 had actually made stock option grants to more than fifty percent of non-management employees, as opposed to the other surveyed companies that had made the majority of their employees eligible to receive such grants, but had not actually awarded grants to more than fifty percent of employees. These 105 companies are referred to as surveyed stock option firms in the tables, and are sometimes broken into a "grants to $<50 \%$ of non-management" and a "grants to $>50 \%$ of non-management group". The remaining stock option companies, for which there was no survey data available, are referred to "unknown grants to nonmanagement" and are combined with the surveyed companies to comprise the category "All Stock Option Companies".

We used Standard \& Poor's 1998 CompuStat file (full coverage) to construct several comparison groups. All firms that reported a positive number of employees in either 1996 or 1997 were included in the dataset. We wanted to compare the performance of all broad-based stock option companies to companies similar in size and industry that do not sponsor stock option plans and to the overall population of firms in the economy. We also wanted to see how the surveyed broad-based stock-option companies compared to other broad-based stock option companies that did not respond to the survey, to their non-stock option industry-size peers, and to all other firms. The first comparison group includes all 490 that made more than half of their non-management employees eligible for broad-based stock-option companies (both survey respondents and non-respondents) and the three subgroups (e.g. $<50 \%$ of non-management; $>50 \%$ of non-management; and unknown coverage). A second comparison group was constructed by matching every broad-based stock-option company (both surveyed and non-surveyed) with the next largest and next smallest (in terms of total employment) non-stock option company within the same 2-digit industry. The average performance of the two matched companies was then used for the comparisons. In the tables this group is referred to as the "Paired" companies. The third comparison group is all companies in CompuStat that have not been identified as having broad-based stock option plans.

Performance comparisons are made using three measures, labor productivity, return on assets and market value over book value (Tobin's q). These dependent variables are chosen in order to approximate a firm-level value creation chain. Labor productivity is the metric we chose in order to most closely approximate employee effort. If broadly dispersed stock options provide an incentive or retention effect this would most likely be 
captured by our output measure. Secondly, if indeed broad-based stock options are associated with greater output a second question of interest is if they are ultimately associated with greater profitability. Of course, this is not necessarily the case, it could be that stock option use may actually promote inefficient over investment that harms profitability (Sesil/Lin/Director 2006). Finally, we evaluate the market measure Tobin's q. Again, if stock options promote greater output and profitability we would expect to see this ultimately reflected in the share price. As a note of caution, all of our dependent variables are subject to factors well outside the influence of executives and of course front-line employees. This applies to productivity, but especially is the case for profitability and our market measure. Compensation comparisons are made using data on labor costs per employee. Variables are defined in Table 1.

Table 1: Variable definitions

Variable Definition

\author{
Grants to $50 \%+$ of \\ non-mgt. \\ Grants to $<50 \%$ of \\ non-mgt.
}

Unknown grants to non-mgt.

Stock Option Co.

Paired Co.

Ln (Employment)

Ln (Sales)

Ln (Capital Intensity)

Ln (Productivity)

Return on assets

Tobin's Q

Ln (labour costs per employee)

Industry controls
Survey firms where fifty percent or greater of non-management employees have actually been granted the right to purchase shares after a required vesting period (dummy variable).

Survey firms where less than fifty percent of non-management employees have actually been granted the right to purchase shares after a required vesting period (dummy variable).

Non-survey firms where more than $50 \%$ of non-management employees are eligible to receive stock option grants, but the percent of employees who have actually received stock option grants is unknown (dummy variable).

Company where more than $50 \%$ of non-management employees are eligible to receive stock option grants (dummy variable).

For each broad-based stock option company, the next largest and/or next smallest (in terms of total employment) non-stock option company within the same 2-digit industry (dummy variable).

Natural logarithm of total company employment (in thousands, continuous).

Natural logarithm of total company sales in million dollars, adjusted for inflation with GDP deflator (continuous).

Total property, plant, and equipment (in million dollars) divided by total employment (in thousands), with book values adjusted to current market value using GDP deflator and estimate of age of capital stock (continuous).

Natural logarithm of output per worker (total sales adjusted for inventory changes and inflation divided by the number of employees) (continuous).

[(Income minus adjusted depreciation) $\times 100] /($ inflation adjusted net plant value + current assets - current liabilities) (in million dollars, continuous).

[(Market value + preferred stock + long term debt) / (Capital stock + current assets - current liabilities)] (continuous).

Natural logarithm of total labour expenses divided by number of employees.

2-digit industry codes (dummy variables). 


\section{Analytic strategy}

The performance of broad-based stock option companies is assessed using multiple regression techniques. Both the magnitude of the coefficients and the regression fit may be strongly influenced by extreme values. To check and adjust for the influence of outliers we ran the regressions in four ways: robust regression (assigning lower weights to extreme values); median regression (minimizing the sum of absolute residuals rather than of squared residuals); ordinary least squares regression with the upper and lower 1\% values trimmed; and ordinary least squares regression with the full dataset. The results did not vary substantially across these techniques; here we report results that use robust regression.

The first model is a cross-sectional regression on performance levels in 1997, controlling for labor and capital stocks, and industry effects. The specification is:

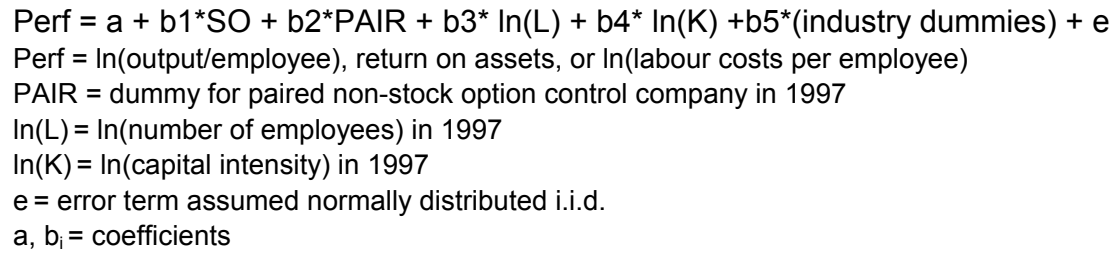

For full variable definitions, please see table 1. Where productivity is the dependent variable, this represents the Cobb-Douglas production function equation. In a related specification, the SO dummy variable is replaced by three dummy variables, representing (1) companies where $50 \%$ or more of non-management employees have actually been granted stock options, (2) companies where fewer than $50 \%$ of non-management employees have actually been granted stock options, and (3) companies for which the actual percentage of employees who have received grants is unknown, because they were not a survey respondent.

For a finer test of the relationship between broad based stock option plans and performance, a separate specification is run on the differences in levels of performance between the stock option companies and their pairs. The specification is modeled as:

$$
\left(\text { Perf }_{S O}-\text { Perf }_{\text {NSO }}\right)=a+b_{1}{ }^{*}\left(\ln (\mathrm{L})_{\text {SO }}-\ln (\mathrm{L})_{\text {NSO }}\right)+b_{2}{ }^{*}\left(\ln (K)_{\text {SO }}-\ln \left(K_{\text {NSO }}\right)+\left(e_{S O}-e_{N S O}\right)\right.
$$

In this model, the SO subscript refers to a stock option firm, the NSO subscript refers to a same-industry/same-size paired firm without a stock option plan, and the intercept represents the estimated difference in performance between pairs after controlling for differences in labor and capital stocks (all other variables are as defined above and in Table 1). Results for specifications (1) and (2) are reported in Table 5.

Cross-sectional regressions are subject to omitted variable bias, where the variables of interest are correlated with omitted variables in the error term, and the estimated coefficients are biased. Such a bias can easily occur in the current study if, for example, stock option firms are more likely to have high-quality management, and the stock option coef- 
ficient is biased upward as a partial proxy for high-quality management. A possible solution to this problem is to remove any constant omitted variables through a pre/post stock option plan adoption comparisons of company performance levels. Plan adoption dates were not available for most of the stock option companies in our data set. However, almost all broad-based plans for which NCEO had available data were started in the 1990 - eighty four percent of the survey sample did not adopt this type of stock option plan until after 1987. Therefore, one potentially useful way to examine pre- and postadoption performance across firms is to compare mid-80s performance with mid-90s performance. Obviously, this does not clearly establish causality, since performance may have changed just prior to adoption, and any performance changes may be due to one or more accompanying changes in the company. This approach does, however, provide a useful picture of whether these firms are doing better or worse following adoption, shedding light on the role that these plans may play in performance, and the value of further more detailed research. The specification, run on firms that reported data in all years in the 1985-87 and 1995-97 periods, allows for differing effects of labor and capital stock in the two periods:

$$
\begin{aligned}
& \text { Perf }=a+b_{1}{ }^{*} \ln (\mathrm{L})+\mathrm{b}_{2}{ }^{*} \ln (\mathrm{K})+\mathrm{b}_{3}{ }^{*}\left[\ln (\mathrm{L})^{*}(95-97 \text { period dummy })\right]+\mathrm{b}_{4}{ }^{*}\left[\ln (\mathrm{K})^{*}(95-97\right. \\
& \text { period dummy })]+\left[\mathrm{SO}^{*}(85-87 \text { period dummy })\right]+\left[\mathrm{SO}^{*}(95-97 \text { period dummy })\right]+ \\
& {\left[\mathrm{PAIR}{ }^{*}(85-87 \text { period dummy })\right]+\left[\mathrm{PAIR}^{*}(95-97 \text { period dummy })\right]+\text { industry dummies }} \\
& + \text { year dummies }
\end{aligned}
$$

A similar regression was run on the paired comparisons:

$$
\begin{aligned}
& \left(\text { Perf }_{\mathrm{SO}}-\text { Perf }_{\mathrm{NSO}}\right)=a+b_{1}{ }^{*}\left(\ln (\mathrm{L})_{\mathrm{SO}}-\ln (\mathrm{L})_{\mathrm{NSO}}\right)+\mathrm{b}_{2}{ }^{*}\left(\ln (\mathrm{K})_{\mathrm{SO}}-\ln (\mathrm{K})_{\mathrm{NSO}}\right)+\mathrm{b}_{3}{ }^{*}(95-97 \text { pe- } \\
& \text { riod dummy })+\left(\mathrm{e}_{\mathrm{SO}}-\mathrm{e}_{\mathrm{NSO}}\right)
\end{aligned}
$$

In specification (4) the 1985-87 difference between stock option and non-stock option companies is measured by the coefficient a, and the 1995-97 difference is measured by $a+b_{3}$. Results from specifications (3) and (4) are reported in Tables 5 and 6 (where Table 6 uses the annual change in variables between year t- 1 and $t$, rather than the level in year $\mathrm{t}$ ).

To evaluate the relationship of stock option plans to levels and changes in employee compensation, the natural logarithm of labor expenses per employee is used as the dependent variable in specifications (1) and (3), with results reported in Table 8. There were too few companies reporting labor expenses for meaningful paired comparisons using specifications (2) and (4).

\section{Results}

Tables 2-3 provide descriptive statistics and simple comparisons for the survey-based sample and comparison groups in 1997. Table 4 provides the mean and median total shareholder returns along with the cumulative total between 1992 and 1997. Table 2 indicates that broad-based stock option companies, including both survey respondents and non-respondents, are on average larger than other public companies, both in terms of sales and employment. Stock option companies have higher average sales and capital intensity than their pairs (while average employment is similar, reflecting 
the fact that pairing was done on employment). They are more likely than all other public companies to be in the manufacturing and service industry sectors. Average compensation costs per employee in 1997 amounted to $\$ 55,000$ for stock option companies $(n=31)$, compared to $\$ 48,000$ for the paired control group $(n=85)$, and $\$ 51,000$ for all the non-paired non-stock-option companies $(n=581)$.

Table 2: Descriptive statistics, 1997 levels

\begin{tabular}{|c|c|c|c|c|c|c|}
\hline & \multicolumn{4}{|c|}{ Full set of companies, 1997} & \multicolumn{2}{|c|}{$\begin{array}{c}\text { Paired differences, } 1997^{\wedge} \\
\text { (mean of SO minus non-SO paired values) }\end{array}$} \\
\hline & $\begin{array}{l}\text { All non-SO cos. } \\
\text { (1) }\end{array}$ & $\begin{array}{l}\text { Stock option cos. } \\
\text { (2) }\end{array}$ & $\begin{array}{c}\text { All surveyed } \\
\text { Stock option cos. } \\
\text { (3) }\end{array}$ & $\begin{array}{r}\text { Surveyed } \\
\text { SO cos. } w>50 \% \\
\text { (4) }\end{array}$ & $\begin{array}{c}\text { All paired cos. } \\
\text { (5) }\end{array}$ & $\begin{array}{c}\text { Paired } \cos w>50 \% \\
\text { (6) }\end{array}$ \\
\hline Sample size & 7165 & 490 & 105 & 73 & 490 & 73 \\
\hline Sales $(000,000$ 's) & $1151.26(5716.137)$ & $3562.746(8929.085)^{\star \star *}$ & $2769.606(10474.95)^{\star \star \star}$ & $2731.662(11960.170)^{\star *}$ & $784.19(4674.435)^{\star \star *}$ & 879.592 \\
\hline Employees (000's) & $5.654(27.916)$ & $14.451(33.497)^{\star \star \star}$ & $11.888(37.701)^{* *}$ & $10.053(38.186)$ & $-0.364(16.068)$ & $-1.641(13.345)$ \\
\hline $\begin{array}{l}\text { Capital Intensity } \\
\text { (total assets/ee)(000's) }\end{array}$ & $264.338(2800.588)$ & 110.557 (304.687) & 161.843 (448.753) & $156.061(436.980)$ & $-12.717(699.928)$ & $-189.801(1717.53)$ \\
\hline Ln (Sales) & $4.532(2.427)$ & $6.23(2.196)^{\star \star \star}$ & $5.359(2.390)^{\star * *}$ & $4.959(2.521)$ & $0.361(0.902)^{\star * *}$ & $0.074(1.104)$ \\
\hline Ln (Employees) & $-0.598(2.253)$ & $0.868(2.012)^{\star \star \star}$ & $0.171(2.120)^{\star \star *}$ & $-0.261(2.117)$ & $0.001(0.187)$ & $-0.012(0.622)$ \\
\hline Ln (Capital Intensity) & $3.625(1.577)$ & $3.769(1.612)^{\star}$ & $3.811(1.306)$ & $3.912(1.256)$ & $0.122(1.252)^{\star *}$ & $0.025-1.435$ \\
\hline \multicolumn{7}{|l|}{ Industry } \\
\hline Agriculture & $0.35 \%$ & $0.48 \%$ & $1.12 \%$ & $0.25 \%$ & $0.26 \%$ & $0.28 \%$ \\
\hline Mining/construction & $5.56 \%$ & $0.97 \%$ & $2.33 \%$ & $0.79 \%$ & $1.04 \%$ & $0.84 \%$ \\
\hline Manufacturing & $47.87 \%$ & $57.39 \%$ & $60.24 \%$ & $57.9 \%$ & $58.66 \%$ & $58.94 \%$ \\
\hline Communications & $9.81 \%$ & $8.47 \%$ & $8.01 \%$ & $8.42 \%$ & $7.23 \%$ & $7.54 \%$ \\
\hline Wholesale & $4.94 \%$ & $2.9 \%$ & $0.56 \%$ & $3.16 \%$ & $3.1 \%$ & $3.35 \%$ \\
\hline Retail & $8.52 \%$ & $4.6 \%$ & $6.98 \%$ & $3.68 \%$ & $4.91 \%$ & $3.91 \%$ \\
\hline Finance, real estate & $4.84 \%$ & $1.69 \%$ & $7.63 \%$ & $1.32 \%$ & $1.3 \%$ & $0.82 \%$ \\
\hline Service & $18.12 \%$ & $23.49 \%$ & $13.13 \%$ & $24.47 \%$ & $23.51 \%$ & $24.3 \%$ \\
\hline
\end{tabular}

Notes: Standard deviations in parentheses.

* Significantly different from all non-SO companies (cols. 2-4) or from zero (cols. 5-6) at $p<.10{ }^{* *} p<.05{ }^{* \star *} p<.01$

$\wedge$ The actual number of companies is close to three times larger than the number of paired differences.

The non-SO company's value was subtracted from the $\mathrm{SO}$ company's value to create a single paired difference value.

Where there was more than one paired company, the values were averaged before being subtracted from the SO value.

Table 3 indicates that all stock option companies also exhibited significantly higher productivity and ROA in 1997 compared to the full set of companies (adjusted to give lower weight to outliers using robust estimation techniques). In addition they experienced higher levels of growth on all of these measures over the 1992-1997 period. Surveyed broad-based stock-option companies had higher productivity in 1997 compared to all non-stock option companies, but similar levels of ROA. They also experienced higher levels of growth over the 1992-1997 period for productivity, sales, and employment. The paired data comparisons show a similar picture: stock option com- 
panies had higher productivity, employment growth, and sales growth than their peers, but similar levels and growth of ROA.

Table 3: Simple performance comparisons

\begin{tabular}{|c|c|c|c|c|c|c|c|c|c|c|c|c|}
\hline \multirow{2}{*}{ Levels in 1997} & \multicolumn{2}{|c|}{$\begin{array}{c}\text { All non-SO cos. } \\
\text { (1) }\end{array}$} & \multicolumn{2}{|c|}{$\begin{array}{l}\text { Stock option cos. } \\
\text { (2) }\end{array}$} & \multicolumn{2}{|c|}{$\begin{array}{c}\text { All surveyed } \\
\text { stock option cos. } \\
\text { (3) }\end{array}$} & \multicolumn{2}{|c|}{$\begin{array}{c}\text { Surveyed } \\
\text { SO cos. } w>50 \% \\
\text { (4) }\end{array}$} & \multicolumn{2}{|c|}{$\begin{array}{l}\text { All paired cos. } \\
\text { (5) }\end{array}$} & \multicolumn{2}{|c|}{$\begin{array}{c}\text { Paired } \cos w>50 \% \\
\text { (6) }\end{array}$} \\
\hline & & & & & & & & & & & & \\
\hline Productivity--In(sales/ee) & 5.07 & $(0.01)$ & 5.38 & $(0.03)^{\star \star \star *}$ & 5.23 & $(0.09)^{\star \star \star}$ & 5.27 & $(0.11)^{\star \star \star}$ & 0.37 & $(0.36)^{\star \star \star}$ & 0.21 & $(0.13)^{*}$ \\
\hline ROA & 10.02 & $(0.30)$ & 16.5 & $(1.06)^{\star \star *}$ & 8.08 & $(2.92)^{\star \star \star}$ & 0.63 & $(4.58)$ & 0.44 & $(2.37)$ & -7.57 & $(5.37)$ \\
\hline Tobin's Q & 2.44 & $(0.03)$ & 3.67 & $(0.13)^{\star \star *}$ & 3.21 & $(0.21)^{\star \star *}$ & 3.35 & $(0.28)^{\star \star \star}$ & 0.51 & $(0.16)^{\star \star \star}$ & -0.28 & $(0.38)$ \\
\hline TSR & 6.72 & $(0.67)$ & 12.11 & $(2.39)^{\star \star \star *}$ & 9.51 & $(5.19)^{\star}$ & -0.09 & $(6.67)$ & -7.18 & $(2.97)^{\star *}$ & -12.28 & (7.59) \\
\hline $\begin{array}{l}\text { Sample size } \\
\text { Average annual change } 19\end{array}$ & 6618 & & 471 & & 104 & & 67 & & 462 & & 67 & \\
\hline Productivity & 0.03 & $(0.00)$ & 0.04 & $(0.003)^{\star * *}$ & 0.04 & $(0.01)^{\star * *}$ & 0.04 & $(0.01)^{\star \star \star *}$ & 0.02 & $(0.01)^{\star * *}$ & 0.03 & $(0.018)$ \\
\hline ROA & -0.13 & $(0.06)$ & 0.85 & $(0.23)^{\star \star *}$ & 0.58 & $(0.62)$ & 0.45 & $(1.08)$ & 0.20 & $(0.35)$ & -0.06 & (1.59) \\
\hline Tobin's Q & 0.01 & $(0.01)$ & 0.10 & $(0.03)^{\star \star *}$ & 0.02 & $(0.07)$ & -0.07 & $(0.12)$ & -1.78 & $(0.07)^{\star \star \star}$ & -2.28 & $(0.26)^{\star \star \star}$ \\
\hline TSR & -1.55 & $(0.40)$ & -3.55 & $(1.52)^{\star \star}$ & -4.18 & (3.61) & -7.94 & $(5.53)$ & -6.16 & $(1.69)^{\star \star \star}$ & -9.80 & $(5.83)^{*}$ \\
\hline Ln (Sales) & 0.12 & $(0.001)$ & 0.18 & $(0.01)^{\star \star \star}$ & 0.19 & $(0.01)^{\star \star \star}$ & 0.24 & $(0.02)^{\star \star \star}$ & 0.06 & $(0.01)^{\star \star \star}$ & 0.12 & $(0.02)^{\star \star \star}$ \\
\hline Ln (Employment) & 0.05 & $(0.001)$ & 0.11 & $(0.00)^{* * *}$ & 0.12 & $(0.01)^{\star \star \star}$ & 0.16 & $(0.01)^{\star * \star}$ & 0.04 & $(0.01)^{\star \star *}$ & 0.07 & $(0.02)^{* \star *}$ \\
\hline Sample size & 34183 & & 2438 & & 504 & & 316 & & 2328 & & 299 & \\
\hline
\end{tabular}

Notes: Standard errors in parentheses.

${ }^{\star}$ Significantly different from all non-SO companies (cols. $2-4$ ) or from zero (cols. $5-6$ ) at $p<.10{ }^{* *} p<.05{ }^{* * *} p<.01$

Figures represent robust means that minimize influence of outliers.

$\wedge$ The actual number of companies is close to three times larger than the number of paired differences.

The non-SO company's value was subtracted from the SO company's value to create a single paired difference value.

Where there was more than one paired company, the values were averaged before being subtracted from the SO value.

In table 4, we find that that cumulative total shareholder returns are highest for firms that broadly disperse stock options. This is true for firms that broadly distribute options at both the greater than 50\% and less than 50\% level. As discussed in the earlier theoretical review, employees may more highly value option grants that are given during an appreciating market or individual share price. These findings may ultimately have bearing on any impact we may see on productivity, profitability and market over book value.

Tables 5-7 report regression results for productivity, return on assets and Tobin's q, while Table 8 details the compensation differences between stock option and nonstock option firms. Evaluating each of the performance outcomes in turn and starting with productivity levels, in Table 5, column (1) we see that stock option firms in 1997 have approximately $32 \%$ higher productivity than non-stock option firms, and the difference is significant at the 0.01 level. The paired comparisons reported in column (2) show a statistically significant productivity difference between stock option and non stock option companies of about 36\% significantly. The bottom part of Table 5 reports results for a specification where the group of stock option companies has been broken into three subgroups based on the percent of employees who have actually re- 
ceived stock option grants. Productivity levels were significantly higher $(25 \%$ to $35 \%)$ than those of non-stock option companies for both stock option firms with grants to

Table 4: Total shareholder returns, 1992-1997

\begin{tabular}{|c|c|c|c|c|c|c|c|c|c|c|}
\hline \multirow[t]{2}{*}{ Year } & \multicolumn{2}{|c|}{$\begin{array}{l}\text { All Non-SO cos. } \\
\text { (1) }\end{array}$} & \multicolumn{2}{|c|}{$\begin{array}{l}\text { Compustat } 500 \\
\text { (2) }\end{array}$} & \multicolumn{2}{|c|}{$\begin{array}{l}\text { All Stock Option } \\
\text { (3) }\end{array}$} & \multicolumn{2}{|c|}{$\begin{array}{c}\text { Stock Option }>50 \% \\
\text { (4) }\end{array}$} & \multicolumn{2}{|c|}{$\begin{array}{c}\text { Stock Option }<50 \% \\
\text { (5) }\end{array}$} \\
\hline & Mean & Median & Mean & Median & Mean & Median & Mean & Median & Mean & Median \\
\hline \multicolumn{11}{|c|}{ All cos. reporting in given year: } \\
\hline 1992 & $33.7 \%$ & $10.1 \%$ & $17.0 \%$ & $10.3 \%$ & $29.7 \%$ & $15.3 \%$ & $9.7 \%$ & $-4.7 \%$ & $25.1 \%$ & $7.7 \%$ \\
\hline 1993 & $33.0 \%$ & $11.7 \%$ & $47.1 \%$ & $15.6 \%$ & $31.9 \%$ & $20.0 \%$ & $32.6 \%$ & $29.8 \%$ & $4.3 \%$ & $6.1 \%$ \\
\hline 1994 & $-4.5 \%$ & $-9.3 \%$ & $2.5 \%$ & $1.7 \%$ & $10.0 \% * * *$ & $5.0 \%$ & $16.1 \%$ * & $-0.7 \%$ & $4.6 \%$ & $9.8 \%$ \\
\hline 1995 & $31.8 \%$ & $16.3 \%$ & $33.9 \%$ & $30.2 \%$ & $51.4 \%^{\star * *}$ & $38.3 \%$ & $72.9 \%$ *** & $44.4 \%$ & $42.7 \%$ & $45.6 \%$ \\
\hline 1996 & $35.4 \%$ & $8.7 \%$ & $24.6 \%$ & $20.9 \%$ & $19.9 \%$ & $14.2 \%$ & $9.0 \%$ & $5.9 \%$ & $23.3 \%$ & $13.1 \%$ \\
\hline 1997 & $31.7 \%$ & $9.7 \%$ & $28.8 \%$ & $27.8 \%$ & $16.4 \%$ & $13.3 \%$ & $5.9 \%$ & $-7.1 \%$ & $25.5 \%$ & $21.9 \%$ \\
\hline \multicolumn{11}{|c|}{ Cos. reporting in every year: } \\
\hline 1992 & $34.9 \%$ & $11.1 \%$ & $17.2 \%$ & $10.3 \%$ & $29.7 \%$ & $15.3 \%$ & $9.7 \%$ & $-4.7 \%$ & $25.1 \%$ & $6.3 \%$ \\
\hline 1993 & $35.8 \%$ & $12.8 \%$ & $47.7 \%$ & $15.1 \%$ & $32.1 \%$ & $19.6 \%$ & $34.1 \%$ & $25.7 \%$ & $4.2 \%$ & $5.8 \%$ \\
\hline 1994 & $-1.7 \%$ & $-7.1 \%$ & $3.0 \%$ & $1.8 \%$ & $10.9 \% * * *$ & $5.8 \%$ & $23.4 \%$ * & $0.1 \%$ & $4.4 \%$ & $7.2 \%$ \\
\hline 1995 & $33.4 \%$ & $19.3 \%$ & $34.0 \%$ & $30.9 \%$ & $45.7 \%$ ** & $37.2 \%$ & $67.2 \%$ ** & $57.1 \%$ & $46.3 \%$ & $44.3 \%$ \\
\hline 1996 & $23.2 \%$ & $11.6 \%$ & $24.0 \%$ & $20.5 \%$ & $20.2 \%$ & $14.2 \%$ & $11.7 \%$ & $11.9 \%$ & $24.9 \%$ & $14.8 \%$ \\
\hline 1997 & $46.3 \%$ & $17.4 \%$ & $29.3 \%$ & $29.3 \%$ & $21.3 \%$ & $20.9 \%$ & $9.2 \%$ & $-5.5 \%$ & $30.5 \%$ & $30.8 \%$ \\
\hline \multicolumn{11}{|l|}{ Avg. individual company: } \\
\hline cumulative return^ $^{\wedge}$ & $193.1 \%$ & $81.8 \%$ & $275.0 \%$ & $151.7 \%$ & $303.2 \%$ *** & $163.9 \%$ & $232.5 \%$ & $108.9 \%$ & $318.9 \%$ & $128.0 \%$ \\
\hline yearly return ${ }^{\wedge}$ & $19.6 \%$ & $10.5 \%$ & $24.6 \%$ & $16.6 \%$ & $26.2 \%^{* * *}$ & $24.0 \%$ & $22.2 \%$ & $13.1 \%$ & $27.0 \%$ & $14.7 \%$ \\
\hline
\end{tabular}

* Significantly different from non-SO companies at $p<.10{ }^{* *} p<.05{ }^{* * *} p<.01$

${ }^{\wedge}$ Average cumulative and yearly returns are calculated just for those companies that reported data in each year from 1992 to 1997

These represent the average of individual company returns, not the portfolio returns.

Note: These results give equal weight to each company's data, in contrast to the regression results in Tables 3-6 which use robust regression to minimize the influence of outlying values.

$50 \%+$ of non-management employees, and those companies where the actual percent of grantees was unknown, whereas the difference between non-stock option companies and companies with grants to less than 50\% of employees was smaller - about $12.5 \%$ - and statistically insignificant. It should be noted that the sample size for the later group was rather small, at 32 companies. Table 6 shows that productivity levels increased by about $22 \%$ after the adoption of broad-based stock option plans (row 5 , column 1). To put these findings in context, the productivity of the non-stock option same-industry/same-size pairs increased by only $5 \%$ over the same period (table 6 , row 6 , and column 1). Therefore, stock option companies experienced a productivity increase that was about $17 \%$ to $18 \%$ higher compared to their pairs, and the difference was statistically significant at the 0.01 level (table 6, row 7, columns 1 and 2). Productivity growth among stock option companies was faster than that among their non-stock option pairs both before and after plan adoption, according to the results 
shown in Table 7 (rows 1 and 2, column 2), but growth did not significantly accelerate after adoption, as evident from the results in row 7, columns 1 and 2 .

Regarding the other measure of company performance, return on assets, Table 5 shows that the performance of all stock option companies does not differ significantly from all non-stock option companies or the paired companies. When the model was run with the 3 stock option company subgroups rather than a single stock option company dummy, a more complicated pattern emerged - ROA was significantly lower $(6.6 \%)$ for the firms with grants to $50 \%+$ of non-management employees, but significantly higher $(2.5 \%)$ for the non-survey stock option firms. It is difficult to speculate what this pattern suggests; it should be noted that the non-survey stock option firms group is about five times larger than the group of firms with grants to $50 \%+$ of nonmanagement employees.

Table 5: Stock options plans and 1997 performance levels

\begin{tabular}{|c|c|c|c|c|c|c|c|}
\hline \multirow[b]{2}{*}{ Independent variables } & \multirow{2}{*}{$\begin{array}{l}\text { variables: } \\
\text { Sample: }\end{array}$} & \multicolumn{2}{|c|}{ Ln(output/employee) } & \multicolumn{2}{|c|}{ Tobin's Q } & \multicolumn{2}{|c|}{ Return on Assets } \\
\hline & & $\begin{array}{r}\text { Full set } \\
\text { (1) }\end{array}$ & $\begin{array}{r}\text { Paired } \\
\text { (2) }\end{array}$ & $\begin{array}{l}\text { Full set } \\
\text { (3) }\end{array}$ & $\begin{array}{r}\text { Paired } \\
\text { (4) }\end{array}$ & $\begin{array}{l}\text { Full set } \\
(5)\end{array}$ & $\begin{array}{r}\text { Paired } \\
(6)\end{array}$ \\
\hline Stock option co. & & $\begin{array}{l}0.277^{* * *} \\
(8.97)\end{array}$ & $\begin{array}{l}0.306^{* \star *} \\
(8.61)\end{array}$ & $\begin{array}{l}0.61^{* * *} \\
(6.33)\end{array}$ & $\begin{array}{l}0.62 \text { *** } \\
(3.75)\end{array}$ & $\begin{array}{r}1.14 \\
(0.99)\end{array}$ & $\begin{array}{r}0.87 \\
(0.61)\end{array}$ \\
\hline Paired co. & & $\begin{array}{l}0.002 \\
(0.07)\end{array}$ & & $\begin{array}{r}0.01 \\
(0.64)\end{array}$ & & $\begin{array}{r}1.41 \\
(1.46)\end{array}$ & \\
\hline Ln(total employment) & & $\begin{array}{l}-0.316^{* * *} \\
(41.39)\end{array}$ & $\begin{array}{l}-0.603^{* * *} \\
(3.20)\end{array}$ & $\begin{array}{r}0.36^{* * *} \\
(15.15)\end{array}$ & $\begin{array}{r}1.44 * \\
(1.67)\end{array}$ & $(19.74)^{5.52 * * *}$ & $\begin{array}{r}8.39 \\
(1.13)\end{array}$ \\
\hline $\operatorname{Ln}$ (net assets) & & $\begin{array}{r}0.30^{* * *} \\
(46.13)\end{array}$ & $\begin{array}{l}0.261^{* * *} \\
(9.12)\end{array}$ & $\begin{array}{l}-0.29^{* * *} \\
(14.21)\end{array}$ & $\begin{array}{l}-0.38^{* * *} \\
(2.72)\end{array}$ & $\begin{array}{l}-1.15^{* * *} \\
(4.87)\end{array}$ & $(1.66)^{-1.98}$ \\
\hline $\begin{array}{l}\text { 2-digit industry dummies } \\
\mathrm{N}\end{array}$ & & $\begin{array}{r}\text { Yes } \\
6630\end{array}$ & 444 & $\begin{array}{r}\text { Yes } \\
6379 \\
\end{array}$ & 434 & $\begin{array}{r}\text { Yes } \\
6716\end{array}$ & 443 \\
\hline $50 \%+$ coverage of non-mgt. & & $\begin{array}{l}0.22^{* * *} \\
(2.96)\end{array}$ & $\begin{array}{l}0.213^{* *} \\
(2.35)\end{array}$ & $\begin{array}{l}0.53 \text { ** } \\
(2.32)\end{array}$ & $\begin{array}{r}-0.163 \\
(0.20)\end{array}$ & $\begin{array}{l}-6.6^{* *} \\
(2.40)\end{array}$ & $\begin{array}{l}-6.2 \text { * } \\
(1.73)\end{array}$ \\
\hline$<50 \%$ coverage of non-mgt. & & $\begin{array}{l}0.118 \\
(0.17)\end{array}$ & $\begin{array}{l}0.061 \\
(0.48)\end{array}$ & $\begin{array}{r}0.20 \\
(0.63)\end{array}$ & $\begin{array}{l}0.213 \\
(0.36)\end{array}$ & $\begin{array}{r}0.71 \\
(0.19)\end{array}$ & $\begin{array}{r}-0.18 \\
(0.01)\end{array}$ \\
\hline Unknown coverage of non-mgt. & & $\begin{array}{l}0.301^{* * *} \\
(8.71)\end{array}$ & $\begin{array}{l}0.344 * * \\
(8.53)\end{array}$ & $\begin{array}{l}0.68^{* * *} \\
(6.33)\end{array}$ & $\begin{array}{l}0.824^{* * *} \\
(4.37)\end{array}$ & $\begin{array}{l}2.49 \text { ** } \\
(1.93)\end{array}$ & $\begin{array}{r}1.91 \\
(1.20)\end{array}$ \\
\hline Paired co. & & $\begin{array}{l}0.003 \\
(0.11)\end{array}$ & & $\begin{array}{r}0.01 \\
(0.09)\end{array}$ & & $\begin{array}{r}1.47 \\
(1.52)\end{array}$ & \\
\hline Ln(total employment) & & $\begin{array}{l}-0.316^{* * *} \\
(41.36)\end{array}$ & $\begin{array}{l}-0.635^{* * *} \\
(3.35)\end{array}$ & $\begin{array}{r}0.37^{* * *} \\
(15.16)\end{array}$ & $\begin{array}{r}1.24 \\
(1.40)\end{array}$ & $\begin{array}{r}5.5^{* * *} \\
(19.66)\end{array}$ & $\begin{array}{r}7.05 \\
(0.94)\end{array}$ \\
\hline $\operatorname{Ln}$ (net assets) & & $\begin{array}{r}0.297 \quad * * * \\
(46.10)\end{array}$ & $\begin{array}{l}0.262 \\
(9.13)\end{array}$ & $\begin{array}{r}-0.29 \text { *** } \\
(14.26)\end{array}$ & $\begin{array}{l}-0.37^{* * *} \\
(2.67)\end{array}$ & $\begin{array}{l}-1.15^{* * *} \\
(4.88)\end{array}$ & $(1.47)^{-1.76}$ \\
\hline 2-digit industry dummies & & Yes & & Yes & & Yes & \\
\hline $\mathrm{N}$ & & 6630 & 444 & 6379 & 434 & 6716 & 443 \\
\hline
\end{tabular}


Table 6: Stock options plans and pre-post change in performance levels

\begin{tabular}{|c|c|c|c|c|c|c|c|}
\hline \multirow{2}{*}{\multicolumn{2}{|c|}{ Independent variables }} & \multicolumn{2}{|c|}{ Ln(output/employee) } & \multicolumn{2}{|c|}{ Tobin's Q } & \multicolumn{2}{|c|}{ Return on Assets } \\
\hline & & $\begin{array}{l}\text { Full } \\
(1)\end{array}$ & $\begin{array}{l}\text { Paired } \\
\text { (2) }\end{array}$ & $\begin{array}{l}\text { Full } \\
(3)\end{array}$ & $\begin{array}{l}\text { Paired } \\
\text { (4) }\end{array}$ & $\begin{array}{l}\text { Full } \\
(5)\end{array}$ & $\begin{array}{l}\text { Paired } \\
(6)\end{array}$ \\
\hline \multicolumn{8}{|c|}{$\begin{array}{l}\text { All companies w/data in both periods }{ }^{\wedge} \\
\text { Stock option companies }\end{array}$} \\
\hline 1 & $1985-87$ & $\begin{array}{l}0.093^{* * *} \\
(4.35)\end{array}$ & $\begin{array}{l}0.054 * \\
(1.81)\end{array}$ & $\begin{array}{l}0.312^{* *} \\
(6.80)\end{array}$ & $\begin{array}{l}0.269^{* * *} \\
(3.28)\end{array}$ & $\begin{array}{l}0.540 \\
(0.87)\end{array}$ & $\begin{array}{l}0.354 \\
(0.41)\end{array}$ \\
\hline 2 & $1995-97$ & $\begin{array}{l}0.2944^{* * *} \\
(13.56)\end{array}$ & $\begin{array}{l}0.2222^{* * *} \\
(7.33)\end{array}$ & $\begin{array}{l}0.659 \text { ** } \\
(14.18)\end{array}$ & $\begin{array}{l}0.299 * * * \\
(3.59)\end{array}$ & $\begin{array}{l}4.319^{* *} \\
(6.88)\end{array}$ & $\begin{array}{l}2.40^{* * *} \\
(2.75)\end{array}$ \\
\hline \multicolumn{8}{|c|}{ Paired companies } \\
\hline 3 & $1985-87$ & $\begin{array}{r}-0.005 \\
(0.30)\end{array}$ & & $\begin{array}{r}-0.037 \\
(0.98)\end{array}$ & & $\begin{array}{l}0.467 \\
(0.94)\end{array}$ & \\
\hline 4 & $1995-97$ & $\begin{array}{l}0.048^{* * *} \\
(2.76)\end{array}$ & & $\begin{array}{l}0.094^{* *} \\
(2.47)\end{array}$ & & $\begin{array}{l}1.723 \text { ** } \\
(3.43)\end{array}$ & \\
\hline \multicolumn{8}{|c|}{ Change from $1985-87$ to $1995-97$} \\
\hline 5 & Stock option co. & $\begin{array}{l}0.201 * * * \\
(6.82)\end{array}$ & & $\begin{array}{l}0.347^{* *} \\
(5.53)\end{array}$ & & $\begin{array}{l}3.779 * * \\
(4.43)\end{array}$ & \\
\hline 6 & Paired co. & $\begin{array}{l}0.053^{* *} \\
(2.24)\end{array}$ & & $\begin{array}{l}0.131^{* *} \\
(2.54)\end{array}$ & & $\begin{array}{l}1.256 * \\
(1.84)\end{array}$ & \\
\hline 7 & Difference & $\begin{array}{l}0.148^{* * *} \\
(4.22)\end{array}$ & $\begin{array}{l}0.1688^{* * *} \\
(3.96)\end{array}$ & $\begin{array}{l}0.216 \text { ** } \\
(2.85)\end{array}$ & $\begin{array}{l}0.030 \\
(0.26)\end{array}$ & $\begin{array}{l}2.523 \text { ** } \\
(2.48)\end{array}$ & $\begin{array}{l}2.048 \text { * } \\
(1.68)\end{array}$ \\
\hline & Total observations & 12870 & 768 & 11088 & 630 & 13032 & 774 \\
\hline & Number of stock option companies represented & 165 & 128 & 153 & 105 & 166 & 129 \\
\hline & Number of paired companies represented & 1980 & 128 & 1695 & 105 & 2006 & 129 \\
\hline
\end{tabular}

Table 7: Stock options plans and pre-post annual growth in performance

\begin{tabular}{|c|c|c|c|c|c|c|c|c|}
\hline & Depend & variables: & Ln(output & nployee) & & bin's $Q$ & Return ol & Assets \\
\hline & Independent variables & Sample: & $\begin{array}{l}\text { Full } \\
(1)\end{array}$ & $\begin{array}{l}\text { Paired } \\
\text { (2) }\end{array}$ & $\begin{array}{l}\text { Full } \\
(3)\end{array}$ & $\begin{array}{l}\text { Paired } \\
\text { (4) }\end{array}$ & $\begin{array}{l}\text { Full } \\
(5)\end{array}$ & $\begin{array}{l}\text { Paired } \\
(6)\end{array}$ \\
\hline & $\begin{array}{l}\text { All companies w/data in both periods^ } \\
\text { Stock option co. }\end{array}$ & & & & & & & \\
\hline 1 & $1985-87$ & & $\begin{array}{l}0.022 \text { ** } \\
(3.18)\end{array}$ & $\begin{array}{l}0.017 \text { ** } \\
(2.12)\end{array}$ & $\begin{array}{l}0.075^{* *} \\
(3.52)\end{array}$ & $\begin{array}{l}-0.483^{* * *} \\
(5.38)\end{array}$ & $\begin{array}{l}0.583 * \\
(1.82)\end{array}$ & $\begin{array}{r}-0.087 \\
(0.18)\end{array}$ \\
\hline 2 & $1995-97$ & & $\begin{array}{r}0.01 \\
(1.46)\end{array}$ & $\begin{array}{l}0.022 \\
(2.70)\end{array}$ & $\begin{array}{l}0.173^{* *} \\
(8.14)\end{array}$ & $\begin{array}{l}-1.672^{* * *} \\
(18.66)\end{array}$ & $\begin{array}{l}0.799 \text { ** } \\
(2.49)\end{array}$ & $\begin{array}{r}0.52 \\
(1.07)\end{array}$ \\
\hline & Paired co. & & & & & & & \\
\hline 3 & $1985-87$ & & $\begin{array}{l}0.004 \\
(0.77)\end{array}$ & & $\begin{array}{l}0.014 \\
(0.75)\end{array}$ & & $\begin{array}{r}-0.034 \\
(0.13)\end{array}$ & \\
\hline 4 & $1995-97$ & & $\begin{array}{l}0.001 \\
(0.25)\end{array}$ & & $\begin{array}{l}0.072 \text { ** } \\
(4.01)\end{array}$ & & $\begin{array}{l}0.419 \\
(1.60)\end{array}$ & \\
\hline & Change from $1985-87$ to $1995-97$ & & & & & & & \\
\hline 5 & Stock option co. & & $\begin{array}{r}-0.012 \\
(1.24)\end{array}$ & & $\begin{array}{l}0.098 \text { ** } \\
(3.38)\end{array}$ & & $\begin{array}{l}0.216 \\
(0.49)\end{array}$ & \\
\hline 6 & Paired co. & & $\begin{array}{r}-0.003 \\
(0.37)\end{array}$ & & $\begin{array}{l}0.058 \text { ** } \\
(2.39)\end{array}$ & & $\begin{array}{l}0.453 \\
(1.26)\end{array}$ & \\
\hline 7 & Difference & & $\begin{array}{r}-0.009 \\
(0.77)\end{array}$ & $\begin{array}{l}0.005 \\
(0.41)\end{array}$ & $\begin{array}{r}0.04 \\
(1.11)\end{array}$ & $\begin{array}{c}-1.189 \text { *** } \\
(9.34)\end{array}$ & $\begin{array}{r}-0.237 \\
(0.44)\end{array}$ & $\begin{array}{r}0.60 \\
(0.88)\end{array}$ \\
\hline & Total observations & & 11478 & 696 & 9648 & 588 & 11532 & 696 \\
\hline & Number of stock option companies represented & & 152 & 116 & 144 & 98 & 152 & 116 \\
\hline & Number of paired companies represented & & 1761 & 116 & 1464 & 98 & 1770 & 116 \\
\hline
\end{tabular}

${ }^{*} p<.10{ }^{* *} p<.05 \quad{ }^{* * *} p<.01$

Based on robust regressions run on all companies with complete data for the 1985-87 and 1995-97 periods. Controls include In(employment) and In(assets) interacted with each period, plus year dummies and 2-digit industry dummies. 
The results for the Tobin's q (market over book value) can be found in tables 5 and 6 . We find an increased level of Tobin's q in firms that broadly distribute stock options, (table 5) and in the difference between the mid 80s and the mid 90s (table 6) however, we do not find there to be a significant growth in Tobin's q between the two periods (table 7).

\section{Table 8: Compensation levels and growth}

Dependent variable: In(labor costs per employee)

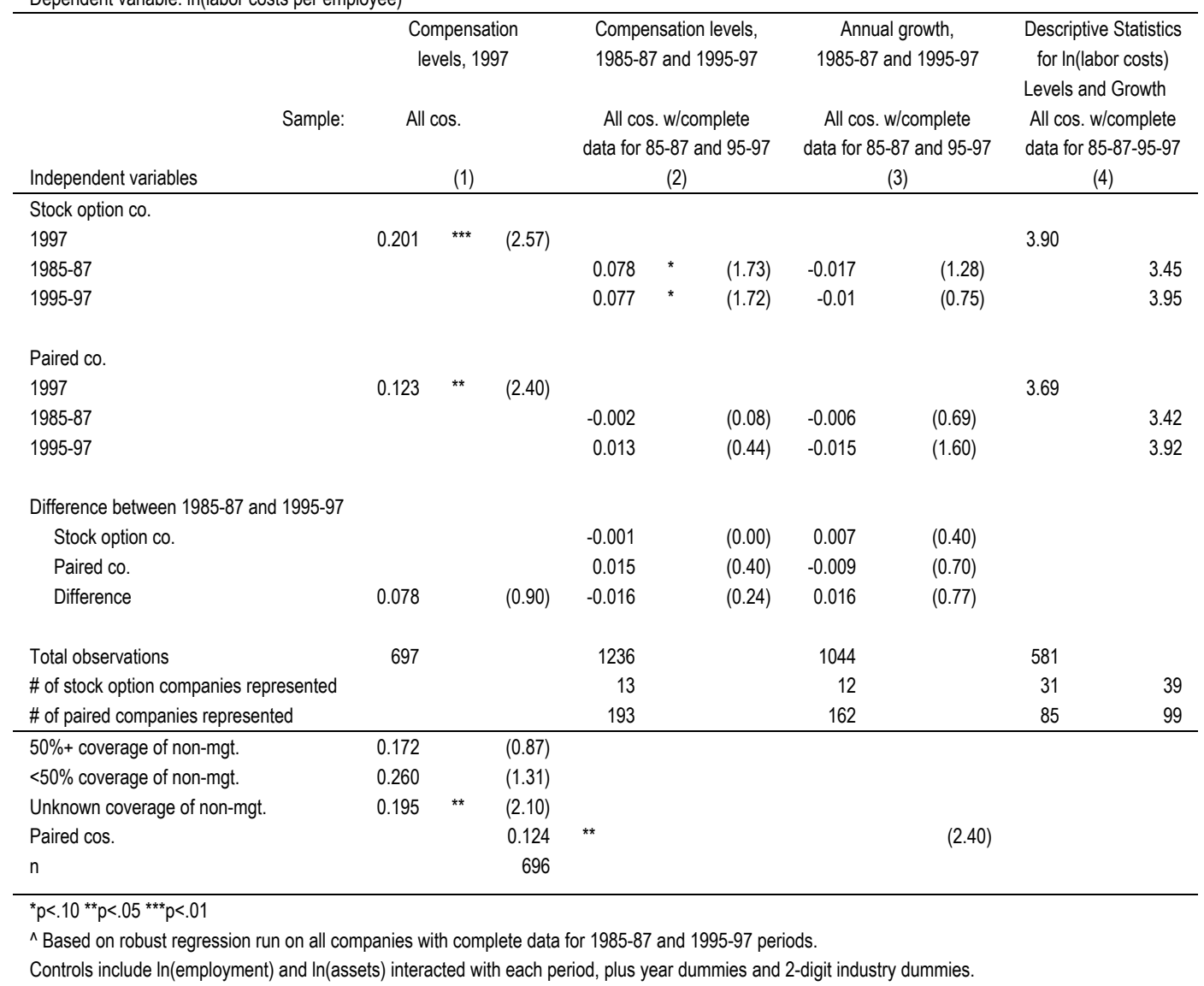

Finally, Table 8 presents the results of the compensation cost levels and growth analysis. The compensation cost levels of stock option companies in 1997 are about $22 \%$ higher than those of all non-stock option companies, and 9\% higher than those of their sameindustry/same-size pairs. This latter figure is very close to the estimated pay differential in both the pre-adoption (1985-87) and post-adoption (1995-97) periods, as shown in table 8 , column 2. The annual growth in compensation between the two periods was not different between the two groups of companies. These results indicate that the stock option companies paid their employees close to $9 \%$ more than similar other firms before they instituted stock options, and maintained this compensation cost differential after instituting stock options; stock option firms did not significantly increase their compensation 
cost after the introduction of stock options relative to non-stock option companies (table 8 , columns 2 and 3). Based on these results, it would appear that stock option companies did not pay their employees poor wages and use stock options to make up for it. Also, there is no evidence that the stock option companies cut fixed wages and substituted stock options for them. In short, the stock option companies had the same fixed wage increases as other non-stock option companies during this period, and continued to maintain their relative advantage of higher compensation. These results should be interpreted with caution, as unfortunately few companies provide their labour cost data in Compustat. The sample size for this analysis is small, at about 30 stock option companies.

In sum, these results indicate that the companies that decided to adopt broad based stock option plans were more productive and more profitable than their same-size/sameindustry pairs, and they paid their employees higher base wages before they adopted their stock option plans. We also found strong evidence that both productivity and profitability levels increased following the adoption of broad-based stock option plans, while compensation costs continued to be relatively higher than those of similar companies; the growth rates for all three of these measures did not accelerate after plan adoption.

\section{Discussion}

The overall picture that emerges is that stock option firms are clearly different from other firms in having higher productivity and profitability levels compared to their industry/size peers, both before and after adopting broad-based stock option plans. Also, productivity, profitability and market value levels increased significantly after the adoption of these plans, and these increases were substantially larger than the increases experienced by similar firms without broad based stock option plans over the same time period. These effects were found not just in a single industry sector such as high-technology or software, where broad-based stock options are particularly common, but across a broad range of industries.

The results we present here line up well when taken as a whole. Initially, we find a mixture of positive performance effects associated with the use of broad-based stock options. We find greater levels of performance for all three of our performance measure (e.g. productivity, profitability, and market value), however, we do not find there to be any impact on the growth of any of these three dependent variables. Also, an important finding in our work is that apparently stock options are not a substitute for fixed wages. Wage substitution theory would predict that where stock options are used it would be as a replacement for fixed wages. We do not find any evidence that stock options are indeed used in this capacity. This is an important finding that supports the work of Larcker et al. (1991) and Hallock and Olson (2006). In summary, our findings include the following; stock options are not a substitute for fixed wages, we observe greater levels of productivity, profitability and market value and our firms have upward trending stock prices, this may suggest that broad-based stock options are having an incentive or retention effect.

However, there are important qualifiers and extension needed for this work. Caution needs to be exercised in the interpretation of these results. The structure of our empirical test does not allow us to be declarative about causality. We do not have start date 
data so we are not able to conduct a pre post study that would better allow us to control for other factors influencing performance. In addition, the fact that we do not see an impact on growth may mean we are picking-up already greater levels of output, profit and market value. While we find overall support for the wage compliment and increase in productivity we find little support for the predictions from agency theory. While the results from one paper certainly does not warrant the wholesale rejection of the agency-theoretic, these results taken with the findings of other similar work (Sesil, et.al. 2003) suggests an agency theory framework does not adequately describe what we are observing related to the impact of broad-based stock options.

Further research is needed to understand the psychological mechanisms through which broad-based stock options influence employee behavior. We need to understand whether certain ways of structuring broad-based stock option programs, or combining stock option programs with other human resource management practices such as participation programs or teams, affects the impact of such programs on corporate performance. Given the tremendous growth in broad-based stock option plans over the 1990's, such research will be important in understanding labor markets and wage structures in the coming decades. In addition, a well thought-out theoretical framework needs to be developed in order to better predict when and where stock options will promote optimal performance.

\section{References}

Benartzi, S. (2001): Excessive Extrapolation and the Allocation of 401(k) Accounts to Company Stock. In: Journal of Finance 56 (5): 1747-1764.

Benartzi, S./Thaler, R. H.: Naïve Diversification Strategies in Defined Contribution Savings Plans. In American Economic Review, 91 (1): 79-98.

Bernstein, J./Mishel, L. (2004): Weak recovery claims new victim: Workers' wages'. In: Economic Policy Institute Issue Brief \# 196.

Blasi, J. R./Kruse, D. L./Bernstein, A. (2003): In the company of owners. New York: Basic Books.

Carpenter, J. (2004): Punishing free riders: How group size affects mutual monitoring and the provision of public goods. In: IZA Discussion Paper No. 1337, Institute for the Study of Labor.

Core, J. E./Guay, W. (2001): Stock options plans for non-executive employees. In: Journal of Financial Economics, 61: 253-287.

Eisenhardt, K. M. (1988): Agency - and institutional - Theory explanations: The Case of the Retail Sales Compensation. In: Academy of Management Journal, 31(3): 488-511.

Fehr, E./Gachter, S. (2000): Cooperation and punishment in public goods experiments. In: American Economic Review, 90: 980-994.

Ferrarini G./Moloney, N./Vespro, C. (2003): Executive Remuneration in the EU: Comparative Law and Practice. In: ECGI Working Paper, June 2003, Paper \# 09/2003.

Gerhart, B./Milkovich, G. T. (1990): Organizational differences in managerial compensation and financial performance. In: Academy of Management Journal, 11(4): 663-691.

Hall, B. J./Liebman, J. B. (1998): Are CEOs really paid like bureaucrats? In: The Quarterly Journal of Economics, 113(3): 653-691.

Hall, B. J./Murphy, K. L. (2002): Stock Options for Undiversified Executives. Journal of Accounting and Economics, 33: 3-42.

Hall, B. J./Murphy, K. L. (2003): The trouble with stock options. In: The Journal of Economic Perspectives, 17: 49-70.

Hallock, K. F./Olson, C. A. (2006): The Value of Stock Options to Non-Executive Employees. National Bureau of Economic Research Working Paper \#11950. 
Huddart, S./Lang, M. (1996): Employee Stock Option Exercises: An Empirical Analysis. In: Journal of Accounting and Economics, 21, (1): 5-43.

Ittner, C. D./Lamberbert, R. A./Larcker, D. F. (2003): The structure and performance consequences of equity grants to employees of new economy firms. In: Journal of Accounting and Economics, 34: 89-127.

Jensen, M. C./Meckling, W. M. (1976): Theory of the firm: Managerial behavior, agency costs, and ownership structures. In: Journal of Financial Economics, 3: 305-360.

Kleiner, M. M./Bouillon, M. L. (1988): Providing business information to production workers: Correlates of compensation and profitability. In: Industrial and Labor Relations Review. XLI: 605-617.

Kroumova, M. K./Sesil, J. C./Kruse, D. L./Blasi, J. R. (2002): Broad-based employee stock options - A union-non-union comparison. In: Lewin, D./Kaufman, B. (Eds) Advances in Industrial and Labor Relations, 11: 69-94. New York, NY: JAI Press.

Kruse, D. L. (1993): Profit sharing: Does it make a difference? Kalamazoo, MI: W.E. Upjohn Institute for Employment Research.

Lambert, R./Larcker, D./Verracchia, R. (1991): Portfolio considerations in valuing executive compensation. In: Journal of Accounting Research, 29: 129-149.

Mercer Human Resource Consulting (2006): Mercer snapshot survey of long term incentives in Europe. June 2006.

Mercer Human Resource Consulting (2006): Executive Compensation: The current state and future direction. May 2006.

Milkovich, G. T./Newman, J. M. (2002): Compensation. New York, NY: McGraw-Hill Irwin.

Morishima, M. (1988): Information sharing and firm performance in Japan: Do joint consultation committees help? In: Mimeo, Simon Fraser University, British Columbia.

National Center for Employee Ownership (2000): A growing number of U.S. employees receive stock options. In: Oakland, CA: NCEO Press Release, February 2000.

Sesil, J. C./Kroumova, M. K./Blasi, J. R./Kruse, D. L. (2002): Broad-based employee stock options in U.S. new economy firms. In: British Journal of Industrial Relations, 40(2): 273-294.

Sesil, J. C./Kruse, D. L./Blasi, J. R. (2003): Sharing ownership via employee stock ownership. In: Sun, L. (Ed): Ownership and Governance of Enterprises: Recent Innovative Developments, pp. 96-123. New York, NY: Palgrave Macmillan.

Sesil, J. C./Lin, Y. P./Director, S. M. (2006): The impact of stock option adoption on firm-level profitability. Rutgers University Working Paper.

Weeden, R./Rosen, C./Carberry, E./Rodrick, S. (2001): Current practices in stock option plan design. Oakland, CA: National Center for Employee Ownership.

Weitzman, M./Kruse, D. (1990): Profit sharing and productivity. In: Blinder, A. S. (Ed): Paying for Productivity: A Look at the Evidence, pp. 95-141. Washington, D.C.: Brookings Institution. 